\title{
Do Corporate Governance Disclosures Matter for Bank Cost of Capital? Empirical Evidence from Accounting Statements of Egyptian Banks
}

\author{
Mona A. Elbannan ${ }^{1} \&$ Mohamed A. Elbannan ${ }^{2}$ \\ ${ }^{1}$ Faculty of Management Technology (Finance), German University in Cairo, Cairo, Egypt \\ ${ }^{2}$ Faculty of Commerce, Cairo University, Giza, Egypt
}

Correspondence: Mona Elbannan, Faculty of Management Technology, German University in Cairo, New Cairo, Cairo 11835, Egypt. E-mail: mona.elbannan@guc.edu.eg

Received: September 25, 2014

Accepted: November 30, 2014

Online Published: December 9, 2014

doi:10.5430/afr.v4n1p59

URL: http://dx.doi.org/10.5430/afr.v4n1p59

\begin{abstract}
The purpose of this study is to examine the association between the quality of bank governance mechanisms disclosed in bank annual reports and cost of capital. The Egyptian banking sector has undergone a series of legislative reforms starting with the issuance of the 2003 banking law. The law incorporates the guidelines of the Basel Accords and governance principles, and was declared a major step forward into facing global banking competition and driving financial growth in Egypt. We create two multivariate cross-sectional, time-series regression models to test this relation. Our main results show that there is a highly significant relation between bank governance disclosures and cost of capital. Banks with reported large board size and more executive directors on board are able to obtain finance from cheaper resources. This indicates that cost of equity of Egyptian banks is not just related to accounting performance and risk but also related to how well a bank is governed. Furthermore, the cost of deposits decreases significantly for banks reporting better governance mechanisms.
\end{abstract}

Keywords: Disclosure, Corporate governance, Accounting, Banking, Cost of equity, Cost of deposits, Egypt

\section{Introduction}

The purpose of this paper is to examine the effect of the quality of governance metrics disclosed in firm annual reports on the cost of capital in banks. The Basel Accords I, II, and III provide guidelines for bank regulation to be adopted by all banks all over the world. Banking regulations encourage banks to decrease their credit risk exposure (Barth et al, 2004). (Note 1) In compliance with Basel Accords, the Egyptian government adopted economic reforms in 2004 that aim to improve banking sector performance and effectiveness, enhance risk management practices of the banking sector, and minimize non-performing loans (NPL) caused by poor or non-existent bank governance practices and accounting controls. Reforming the banking sector involved restructuring of state-owned banks, solving non-performing loans problems, and enhancing the Central Bank of Egypt (CBE) banking supervision (CBE, 2007). The reforms in Egypt include the issuance of the 2005 corporate governance code.

As part of the financial reform program, the banking law (No. 88) was issued in 2003 to align the Egyptian banking rules with the Basel requirements. The law mandates stronger capital base to absorb different banks risks. In this case, raising banks' minimum capital requirements will have an effect on the banks cost of capital, as the ensuing reduction of banks' risk should lead to reduction in cost of bank capital. In addition, the banking law addresses some governance issues, including ownership structure, disclosure and transparency, reserve ratios, and board responsibilities and committees. The law sets the rules, which included most of the five corporate governance principles determined by the Organization for Economic Cooperation and Development (OECD).

We choose the Egyptian banking sector as the setting for this study because risk analysis is more relevant to decision making conducted in more risky settings. Egypt is a code law emerging economy that, in the aftermath of the 9/11 events, was severely hit by major liquidity and capital adequacy challenges. These challenges were exacerbated by the emergence of the global financial crisis and the 2011 Egyptian revolution. The multiplicity of risks arising from these events renders governance reporting invaluable for bank managerial and investment decision making and puts its usefulness to the test. Bank restructuring brought about several developments, including shrinking competition, unprecedented misconduct allegations, more diverse ownership characteristics, and more established foreign 
presence. The CBE continued to take disciplinary actions. However, the sector remains characterized by widely varying states of transparency and risk that makes this an ideal setting for examining the impact of governance-related disclosure on managerial and investment decision making (World Bank, 2002). Moreover, we concentrate on a single emerging market because empirical evidence in cross-country studies may be confounded by differences in size, market regulation, risk exposures, and reporting standards. These differences are expected to affect the disclosure-performance-valuation relations.

We estimate OLS regression models to test these relations. The sample consists of Egyptian banks whose financial information is available. We measure governance as a multidimensional composite index comprised of board structure characteristics (board size, board composition, and CEO/Chairman duality) and ownership structure characteristics (ownership concentration, foreign ownership, and institutional ownership). To the best of our knowledge, this is the first study to measure governance in the Egyptian banking sector using a multidimensional self-constructed governance index comprised of six governance indicators: board size, board composition, leadership structure (duality), foreign ownership, institutional ownership, and ownership concentration. We use factor analysis to group the six variables into a single governance score. Moreover, to our knowledge, this is the first research that examines the relation between bank governance and cost of capital in Egyptian banking sector and establishes a link between governance components and cost of capital. That is, we examine the impact of Egyptian bank governance on cost of bank capital including cost of equity and cost of deposits.

The research will be structured as follows: section 2 reviews the literature that investigates the relation between bank governance quality and cost of equity and debt capital, and develop the hypotheses related to these relations. Section 3 defines the study variables and explains model specifications. Section 4 presents the empirical results of the study. Section 5 concludes and section 6 recommends future research.

\subsection{Literature Review}

\subsubsection{The Agency Problem and Corporate Governance}

Separation of ownership and control in organizations creates information asymmetry problems between shareholders and managers and expose shareholders to agency costs. According to agency theory, an agency relationship is a contract between the principal (the owner) and the agent, where, if both parties are utility maximizers, there is good reason to believe that the agent will not always act in the best interests of the principal (Jensen and Meckling, 1976). Corporate governance mechanisms can help mitigate the agency problems by increasing the transparency and disclosure of information, and by reducing the opportunistic behavior of managers through monitoring their actions. Therefore, corporate governance mechanisms play an important role in enhancing the firm value, reducing firms' risks and hence their cost of capital.

Most studies define corporate governance based on either an investor protection or a functional perspective. Studies taking the investor protection perspective define corporate governance as the internal control system which constitutes one of the control mechanisms to resolve the divergence between managers' decisions and those that are optimal from the society's point of view (for example, Jensen, 1993). Studies taking the functional/operational viewpoint believe that corporate governance results in increased access to external financing, lower cost of capital and associated higher firm valuation, better operational performance through better allocation of resources and better management, reduced risk of financial crises, better relationships with all stakeholders (for example, Claessens, 2003).

In financial institutions setting, the corporate governance problem arises from the asymmetric information which causes banks' opaqueness and the government regulations which restricts its activities. Opaqueness enables managers and large investors to manipulate boards of directors and exploit the private benefits of control (Caprio and Levine, 2002). Basel Committee on Banking Supervision (BCBS) adopts the functional view, where it defines corporate governance as involving "the manner in which the business and affairs of banks are governed by their boards of directors and senior management, which affects how they set corporate objectives; operate the bank's business on a day-to-day basis; meet the obligation of accountability to their shareholders and take into account the interests of other recognized stakeholders; align corporate activities and behavior with the expectation that banks will operate in a safe and sound manner, and in compliance with applicable laws and regulations; and protect the interests of depositor" (BCBS, 2006).

\subsection{Corporate Governance Mechanisms and Cost of Capital}

Due to agency problem and conflict of interests, investors will demand high rate of return for this agency risk and thus increase the firm's cost of capital (Poterba, 1991). Another agency problem arises from the conflict of interest 
between firm shareholders and bondholders, where shareholders may take actions, such as taking risky projects or distribute dividends instead of investing in positive net present value projects that induce in increasing debt holder's default risk and therefore cause an increase in the cost of debt (Ashbaugh et al., 2006). In addition to the two previous agency problems, banks have another agency problem which arises because banks are heavily leveraged, and leverage can create agency problem because depositors, who are bank creditors, are less able to monitor and control banks' risk taking.

These conflicts of interests raise the need for corporate governance (Shleifer and Vishny, 1997), as high quality of corporate governance will ensure better access to external financing at a lower cost (La Porta, et al, 1997). Several corporate governance mechanisms can be used through which investors can protect themselves against expropriation by the insiders (La Porta et al, 2000) and therefore, reduce risk and lower the firm's cost of capital. The empirical evidence on a relation between corporate governance and bank cost of capital has been scant.

\subsubsection{Governance and Cost of Equity Capital}

In context of banks, Zimmer and McCauley (1991) defined cost of bank capital as the fee or net spread between bank borrowing and lending rates that a financial product (such as a straight corporate loan, a commitment to lend, and an interest rate swap) must generate in order to increase the market value of the bank, that is, it is the spread or fee that allows the required regulatory capital to earn the rate of return demanded by the market. Governance mechanisms will reduce the cost of a firm's equity by reducing the cost of external monitoring by outside investors, limiting opportunistic insider trading (Chen et al., 2009), mitigating agency costs driven by the problems of moral hazard and adverse selection resulted from information asymmetries (Ashbaugh et al., 2004), reducing the divergence of cash flows from shareholders and thus reduce the cost of capital (Pham et al., 2007).

The literature shows empirically that the cost of capital is affected by several governance mechanisms such as; shareholder rights (Gompers et al., 2003; Cheng et al, 2006; Guedhami and Mishra, 2009; Huang et al., 2009), the legal protection (Chen et al., 2009), disclosure and transparency (Botosan, 1997; Baumann and Nier, 2004; Andrade et al., 2014), and other governance mechanisms such as board structure, ownership structure, and compensation structure (Chen et al., 2003; Ashbaugh et al., 2004; Pham et al., 2007; Shah and Butt, 2009).

Regarding shareholders rights, Gompers et al., (2003) find that shareholders with stronger rights enjoy a lower cost of equity capital. Huang et al. (2009) suggest that managerial ownership could substitute for shareholder rights in affecting the cost of equity capital. Cheng et al. (2006) find that firms with stronger shareholder rights regimes and higher levels of financial transparency are associated with significantly lower costs of equity capital. In addition, strong legal system decreases the auditing costs and lowers the cost of monitoring the company's performance (Lombardo and Pagano, 2000), increases the confidence of investors and decreases risk premium (Chen et al., 2009), provides high legal protection of minority shareholders and thus reduces the firms' cost of capital (La porta et al., 2002).

Ashbaugh et al. (2004) argue that governance attributes intend to reduce agency costs therefore they have significant effects on firms' cost of equity capital directly and also indirectly through reducing systematic risk (Ashbaugh et al., 2004; Giroud and Mueller, 2011; Morellec et al., 2012). Shah and Butt (2009) show that board size is negatively related to cost of equity, managerial ownership has a negative impact on a company's cost of equity, board independence and audit committee independence have a positive although insignificant effect on a company's cost of equity. In context of ownership structure, there is evidence that high insider ownership and presence of institutional blockholders reduce the risk and information asymmetry of the firm and therefore lead investors to demand lower rates of return on capital (Pham et al., 2007). Regarding ownership concentration, cost of equity is increasing in case of the firm is controlled by a single large shareholder (Guedhami and Mishra, 2009).

Regarding disclosure, the third pillar of the most recent Basel Accord focuses on bank disclosure of information in order to reduce information asymmetry. Disclosure requirements increase market efficiency through existence of reliable information and thus, reduce the return on investors investments (Shaffer, 1995), decrease stock volatility which in turn will reduce a bank's cost of capital (Baumann and Nier, 2004), increase the liquidity of the firm's securities, thus reduce a firm's cost of capital (Diamond and Verrecchia, 1991).

Finally, in emerging markets, Chen et al. (2003) examine the impact of disclosure and other non-disclosure corporate governance mechanisms on cost of equity capital for firms from nine emerging Asian economies, and find negative relationship between disclosure and the cost of equity capital, and also a negative relationship between the non-disclosure corporate governance mechanisms, such as board independence and minority shareholder protection, and the cost of equity capital. However, the effect of the non-disclosure corporate governance mechanisms on the 
cost of equity capital is stronger than that of disclosure, after controlling for beta and firm size. They suggest that the role of non-disclosure corporate governance mechanisms is more important than the role of disclosure in reducing the cost of equity capital because the legal protection of investors in emerging markets is weak. Therefore, we hypothesize that bank cost of equity capital is negatively associated with governance quality.

$\mathrm{H}_{1}$ : Cost of equity capital is negatively associated with the level of bank governance quality.

\subsubsection{Corporate Governance and Cost of Debt Capital}

In the context of the agency problem, Ashbaugh et al. (2006) there are two conflicts that increase probability of default and therefore increase cost of debt. The first agency conflict is between the managers and shareholders, where information asymmetry leads to opportunistic managerial behavior causing the firm cash-flow to decrease; therefore the default risk of creditors will increase inducing in higher cost of firm debt. The second agency conflict is between firm shareholders and bondholders, where shareholders may take actions that are against the interests of bondholders, for example shareholders may influence managers to undertake risky projects which increases the riskiness of the firm's future cash flow. In both cases, the debt holder's default risk will increase resulting in higher cost of debt (Ashbaugh et al., 2006; Bhojraj and Sengupta, 2003).

Concerning the cost of debt, corporate governance is important in determining firm credit ratings and therefore the cost of debt, where a credit rating is generally an opinion of the financial ability of an entity to meet its debt obligations in accordance with their terms. (Note 2) Prior literature suggests that the relation between corporate governance and cost of debt is negative, that is good corporate governance can reduce cost of debt (Anderson et al., 2003; Klock et al., 2005). Corporate governance can reduce the firms' default risk, decrease the bond yields and increase their credit ratings and therefore reduce firms' cost of debt financing if they have timely and detailed disclosure (Sengupta, 1998; Qian and Yeung, In Press), have greater institutional ownership and stronger outside control of the board (Bhojraj and Sengupta, 2003), high financial transparency, board independence, board stock ownership and board expertise, and weaker shareholder rights (Ashbaugh et al., 2006), have large board size, high board meeting frequency and audit committee independence as audit committee monitoring of the financial accounting process reduces creditors risk premium and thus the cost of debt (Anderson et al., 2004).

Accordingly, these arguments indicate that corporate governance is used to determine the cost of capital, whereby good corporate governance can reduce cost of capital. This drives the hypothesis that bank cost of deposits is negatively associated with governance quality.

$\mathrm{H}_{2}$ : Bank cost of deposits is negatively associated with the level of bank governance quality.

\section{Method}

The purpose of this study is to examine whether there is a relation between bank governance quality and cost of bank capital. We create two separate OLS regression models to examine the impact of governance quality on cost of capital. We test for a relation by using cross-sectional, time-series regression analyses design. The sample consists of 48 banks operating in Egypt with data covering the period 2000-2009. The sample selection policy for the study hypothesis $(\mathrm{H} 1-\mathrm{H} 2)$ is described below.

\subsection{Sample Selection}

The study hypotheses require cross-sectional regression analyses of the impact of governance on bank performance and cost of capital are conducted. To be included in the sample, a bank must meet the following sample selection criteria (see Table 1):

1) Bank is subject to CBE supervision and the 2003 Banking Law jurisdiction.

2) The bank must not be a branch of a foreign bank.

3) Financial and governance data are available from Bankscope and Kompass Egypt databases, respectively, for at least three years during the period 2000-2009.

4) Daily stock closing prices (i.e. share price data) must be available from the Thomson Reuters 3000 Xtra stock price database for the period corresponding to the study period (2000-2009) for cost of equity capital calculations. 
Sample consists of banks operating in the Egyptian banking sector over the period 2000-2009. The sample banks must have data available from KOMPASS EGYPT Financial Yearbook (Note 3) (Note 4) Bankscope database, banks' financial statements, and Reuters 3000 Xtra stock price data services. The selection criteria resulting in the final sample is detailed below.

Table 1. Sample selection criteria

\begin{tabular}{l|l|l}
\hline Criterion & Number & Percent \\
\hline Total number of banks available from Kompass Egypt and Bankscope during & 62 & 100.00 \\
2000-2009 & $(5)$ & $(8.10)$ \\
Less: Branches of foreign banks & 57 & 91.90 \\
\hline Subtotal & $(14.50)$ \\
$\begin{array}{l}\text { Less: banks with less than 3 continuous years of data on Kompass Egypt and } \\
\text { Bankscope }\end{array}$ & 48 & 77.40 \\
\hline Final sample & 48 & \\
\hline
\end{tabular}

To enhance the power of the empirical analysis, we pool observations across years for the period 2000-2009. No bank may be represented more than once in the sample. This policy results in a maximum number of observations of 480 bank-years (48 banks in 10 years) comprising the final sample for $\mathrm{H}_{1}$ and $\mathrm{H}_{2}$ testing. However, because many data items are missing, number of observations per variable may be lower.

\subsection{Model Specification and Variable Definitions}

In this section, we introduce the variable definitions and test models. Appendix A presents a list of variables and the data sources. Financial and governance data were obtained from Bankscope database, KOMPASS EGYPT, and bank financial statement, while share price information was obtained from Thomson Reuters 3000 Xtra stock price database services.

\subsubsection{Corporate Governance Quality Index}

In determining an overall corporate governance score, the first challenge is that prior research does not agree on a single corporate governance measure (Gompers et al. 2003; Morellec et al., 2012). However, we follow prior literature in measuring governance quality using a self-constructed index. Specifically, we proxy for the bank governance quality using a multidimensional index comprised of six governance indicators: board size (Yermack, 1996), board composition (Beasley 1996), CEO/Chairman duality (Brickley et al., 1997), percentage of institutional investor ownership (Cornett et al., 2007; Huang and Zhu, in press), percentage of foreign ownership (Chow and Wong-Boren, 1987; Huang and Zhu, in press), and percentage ownership of largest blockholder (Claessens et al., 2002) (Note 5).

Leadership structure as proxied by $\mathrm{CEO} /$ Chairman duality is measured by a dummy variable that takes the value of 0 if the CEO is also the Chairman, and 1 otherwise. We follow Brickley et al. (1997) in defining the duality of leadership as CEO and Chairman positions being held by two different persons, while in non-duality leadership (the unitary leadership structure) the two positions are held by one person. Next, we proxy for board structure by board size and board composition. Board size is the number of directors on the board, and board composition is the proportion of non-executives directors (Shah and Butt, 2009; Pham et al., 2007). Further, we proxy for ownership structure by ownership concentration and ownership identification, as used in prior studies. Ownership concentration is the proportion of shares held by the largest blockholder (Claessens et al., 2002), while ownership identification is proxied for by the foreign ownership and the institutional ownership. The foreign ownership is the proportion of shares held by foreign investors (Huang et al., 2009), while institutional ownership is the proportion of shares held by non-foreign institutional investors, including the Egyptian government.

\subsubsection{Cost of Equity Capital}

We estimate bank cost of equity using the Capital Asset Pricing Model (CAPM). The CAPM is the most widely used model to calculate the banks' cost of equity. We follow many studies that estimate bank cost of equity capital by using the CAPM, for example, Barnes and Lopez (2006), Shah and Butt (2009), King (2009), and Pham et al. (2007). In addition, the Federal Reserve System used the CAPM in estimating banks' cost of equity (Barnes and Lopez, 2006). 
Based on the earlier work of Harry Markowitz (1959) who developed the "mean-variance model" or model of portfolio choice, the CAPM was introduced in Sharpe (1964) and Lintner (1965). (Note 6) In the Sharpe-Lintner model, two key assumptions were added to the Markowitz model to identify a portfolio that must be mean-variance-efficient. The first assumption is borrowing and lending at a risk free rate, that is, investors can borrow or lend any amount of money at the risk-free rate of return which is the same for all investors and does not depend on the amount borrowed or lent. The second assumption is that all investors have homogenous expectations; that is, they estimate identical probability distributions for future rates of return. There is complete agreement on the joint distribution of asset returns from $\mathrm{t}-1$ to $\mathrm{t}$. The CAPM equation according to Sharpe and Lintner assumption of risk-free borrowing and lending is expressed as follows:

$R_{E i t}=$ measure of bank $i$ 's industry-adjusted cost of equity capital for year $t$. we follow Barnes and Lopez (2006) in specifying the benchmark single-factor CAPM for equity returns as:

$\mathrm{R}_{E \mathrm{it}}=\mathrm{R}_{\mathrm{ft}}+\beta_{\mathrm{Ei}}\left(\mathrm{R}_{\mathrm{mt}}-\mathrm{R}_{\mathrm{ft}}\right)+e_{\mathrm{it}}$

Where, $\mathrm{R}_{\mathrm{it}}$ is a bank $i$ 's industry-adjusted annual stock return; $\mathrm{R}_{\mathrm{ft}}$ is the risk-free, 90-day Egyptian government Treasury bill rate; $\beta_{\mathrm{Ei}}$ is the bank's 36-month equity beta that measures the covariance between bank $i$ 's annual stock return and the EGX30 annual return on the fiscal year end date of bank $i$; $\mathrm{R}_{\mathrm{mt}}$ is the annual return on the overall market (EGX30) portfolio on the fiscal year end date of bank $i$; and $\varepsilon_{\mathrm{it}}$ is an error term.

From the Sharpe-Lintner CAPM equation, the expected return on an asset is equal to the risk-free rate of return $\mathrm{R}_{\mathrm{ft}}$ plus a risk premium which consists of a market risk premium $\left(\mathrm{R}_{\mathrm{mt}}\right)$ minus the risk free interest rate $\left(\mathrm{R}_{\mathrm{ft}}\right)$ times the market beta of the asset $i$.

\subsubsection{Cost of Debt Capital}

In this study, cost of debt is measured as the pretax cost of deposits; that is the pretax interest rate that the bank promises its depositors. While the rate on deposits is usually determined according to macroeconomic policy set by the CBE, these rates differ according to bank risk (Poterba, 1991). We follow prior research (Anderson et al. 2003, 2004; Klock et al., 2005) in measuring cost of debt as:

$R_{\text {Dit }}=$ bank $i$ 's industry-adjusted cost of deposits for each year $t$.

Where, $R_{D i t}$ is calculated as interest on deposits divided by bank total deposits

\subsubsection{Control Variables}

To increase the validity of the results, we include in the model those factors suggested by prior research to have a significant effect on cost of capital, specifically, bank size, leverage, market beta, loan growth opportunities, credit risk, liquidity, real GDP growth, inflation expectations, the 2008 global financial crisis, and performance. Bank size, $S I Z E$, is defined as the natural log of total assets. Prior research has documented that larger firms tend to have lower costs of equity capital (e.g. Easton, 2004; Cheng et al., 2006). This suggests a negative association between SIZE and the cost of capital. We proxy for bank leverage using FLEV, total debt at the end of the fiscal year, divided by total assets. Gode and Mohanram (2003) show that higher leverage suggests greater credit risk, thus higher cost of capital. we expect a positive relation between FLEV and cost of deposits (Note 7). Prior research documents a positive association between a firm's market beta and the cost of capital (e.g. Botosan, 1997; Gode and Mohanram, 2003). Following Botosan (1997), we measure BETA as a bank's market-model beta coefficient based on 36 consecutive monthly returns. we expect a positive relation on BETA and cost of capital.

Prior research suggests that firms with fewer growth opportunities will have a higher cost of equity capital (e.g. Easton 2004, Huang et al. 2009). we measure $L G R O$ as the 3-year average loan growth rate. Therefore, we expect a negative relation between $L G R O$ and cost of capital. Also, credit risk is a primary determinant of cost of capital. we measure control risk using $L L P$, percentage of loan loss provisions to total loans as a proxy for credit risk, and expect a positive relation with cost of capital. Banks with high levels of liquid assets in cash and government securities may receive lower interest income than banks with less liquid assets (Naceur and Kandil 2009). If the market for deposits is reasonably competitive, then greater liquidity will tend to be negatively associated with future profitability and cash flows, and positively related to risk and cost of capital. To control for differences in bank liquidity, we use $L I Q$, equals the liquid assets of the bank divided by total assets. $L I Q$ is expected to be positively associated with cost of capital.

In periods of real GDP growth, economic activity is above average and banks would benefit from the upward activity level, especially that the level of economic activity at banks is normally positively correlated to Egyptian economic activity. The increasing level of activity should drive up the market expectations of the bank's future cash flows, 
hence resulting in lower cost of capital. we control for overall economic activity using the variable $G D P G$, which is defined as the annual GDP growth rate in Egypt in real terms, as declared by the Ministry of Finance. we expect the relation between $G D P G$ and cost of capital to be negative. Inflation would also affect a bank's cost of capital because of the negative effect of inflation on the expected future stream of cash flows generated by banks. Cost of capital is directly related to the ability of the bank to generate return on capital that compensates capital providers for bank risk. we measure current inflation as CPI, the annual Consumer Price Index announced by the Egyptian Ministry of Finance. we expect a positive relation between $C P I$ and cost of capital.

The year 2008 was characterized by the exacerbation of the global banking crisis, which is expected to have a negative impact on the Egyptian banking sector. Even though Egyptian government officials claim that the crisis did not affect the Egyptian banking sector significantly, the event has to be controlled for due to its potential impact on the research model. we use CRISIS, a dummy variable that assumes the value of 1 if the data year is 2008 and 0 otherwise. Finally, Better accounting-based financial performance results in higher stream of future cash flow and thus lowers bank risk. We include in the model a accounting-based financial performance variable, $R O A$, among the explanatory variables. We expect a negative association between $R O A$ and cost of capital.

\subsubsection{Econometric specification}

To test the two hypotheses, we create two multivariate cross-sectional models that test the impact of bank governance quality on cost of equity capital (Model 1) and cost of deposits (Model 2), respectively. In Model 1, the dependent variable cost of equity, $K(E)$, has been defined above as a bank's industry-adjusted cost of equity capital calculated using the CAPM. In Model 2, the dependent variable cost of deposits, $K(D)$, has been defined above as a bank's industry-adjusted pretax interest on deposits divided by total deposits. The main independent variable bank governance quality, $\mathrm{GOV}$, also has been defined above, as a multidimensional composite index generated by factor analysis of bank score on each of the following indicators: board size, board composition, CEO/Chairman duality, institutional ownership percentage, foreign ownership percentage, and largest blockholder ownership percentage.

We follow prior literature in controlling for specific factors deemed significant in explaining variation in bank cost of capital. Prior research contends that the following are important predictors of bank cost of capital: credit risk, beta, loan growth opportunities, liquidity, Stock exchange listing, financial leverage, size, real GDP growth, inflationary expectations, and performance. Further, we control for financial crisis. These variables and their predicted signs were described above. The primary analysis involves an examination of the significance of the coefficient of the primary variable $G O V$. Finding a significant coefficient is consistent with the theory indicating that governance quality is an important influence on bank cost of capital in Egypt.

Model 1: Bank cost of equity capital $=f$ (Governance Quality, Control variables)

$K(E)_{i t}=\alpha_{0}+\alpha_{1} G O V_{i t}+\alpha_{2} C_{\text {CRISIS }}+\alpha_{3}$ SIZE $_{i t}+\alpha_{4}$ BETA $_{i t}+\alpha_{5} L G R O+\alpha_{6} L I Q_{i t}+\alpha_{7} L L P_{i t}+\alpha_{8} R O A_{i t}+\alpha_{9} G D P G_{i t}$ $+\alpha_{10} C P I_{i t}+\alpha_{11} L_{I S T} T_{\mathrm{it}}+\varepsilon_{\mathrm{j}} \ldots \ldots \ldots \ldots \ldots . \quad($ Model 1)

Variable definitions are shown in Appendix A; $\varepsilon_{i t}=$ error term

Model 2: Bank cost of deposits $=f$ (Governance Quality, Control variables)

$K(D)_{i t}=\gamma_{0}+\gamma_{1} G O V_{i t}+\gamma_{2} C_{R I S I S}+\gamma_{3} S_{I Z E_{i t}}+\gamma_{4} B_{E T A_{i t}}+\gamma_{5} L G R O+\gamma_{6} L I Q_{i t}+\gamma_{7} L L P_{i t}+\gamma_{8} R O A_{i t}+\gamma_{9} G_{D P G}+$ $\gamma_{10} C P I_{i t}+\gamma_{11} F L E V_{i t}+\gamma_{12} L I S T_{\mathrm{it}}+\delta_{\mathrm{j}} \ldots \ldots \ldots \ldots$ (Model 2)

Variable definitions are shown in Appendix A; $\delta_{i t}=$ Error term

The coefficients $\alpha_{1}$ and $\gamma_{1}$ represents the coefficient estimate of the main independent variable, GOV, in Models 1 and 2, respectively. The remaining set of coefficients represents the coefficient estimates for the control variables suggested by prior literature as determinants of cost of capital.

\section{Empirical Results}

In this section, we present the empirical results of the analysis conducted on study models. Models 1 and 2 test the relations between corporate goverance and cost of equity and debt using a cross-sectional design. To control for extraneous industry effects, we follow Cornett et al. (2007) in adjusting the financial variables in all models for the industry averages. Industry-adjusted comparisons permit the examination of firm-specific performance irrespective of any industry-wide factors that may affect accounting-based financial performance (Cornett et al., 2007).

\subsection{Descriptive Statistics}

In this section, we describe the empirical results of testing Models 1-2, where we regress the cost of equity (Model 1) and cost of debt (Model 2), respectively, on bank governance quality and a vector of control variables. Table 2 
presents the statistics for models 1 and 2. It is important to note that financial indicators are industry-adjusted, that is, the industry average for each variable was deducted from the data value of each bank in order to control for industry-wide fluctuations. Table 2 shows the mean GOV and governance components (BSIZE, COMP, FOR, INST, $D U A L$, and $C 1$ ) scores in each GOV quartile. In the best-governed banks (fourth GOV quartile), the average bank is characterized by the following mean values: board size of 6.86 members, non-executives representing $75.85 \%$ of the board, and separation of $\mathrm{CEO} /$ Chairman positions.

On the ownership side, the best-governed banks have foreign ownership of $68.01 \%$, institutional ownership of $97.64 \%$, and largest blockholder ownership of $81.64 \%$. On the other hand, poorly-governed banks have on average a board size of 11.22 members, $86.73 \%$ non-executives, no separation of CEO/Chairman positions, $10.26 \%$ foreign ownership, $57.08 \%$ institutional ownership and $28.39 \%$ ownership by the largest blockholder. That is, the best-governed banks are characterized by relatively smaller boards, lower non-executive director proportion, separation of $\mathrm{CEO} /$ Chairman positions, higher ownership percentage by foreigners and institutional investors, and higher ownership concentration.

In this study, all non-governance and non-macroeconomic measures are expressed in industry-averages. Thus, the interpretation of the figures should focus on the relative rankings of the variables rather than on the individual values (which in themselves would have little meaning). Cost of equity capital and deposits at well-governed banks are lower than those at poorly-governed banks, even after adjusting for the industry averages. The lower cost of capital reflects the lower risk of well-governed banks. Loan loss provisions, beta, liquidity, and financial leverage are lower in well-governed banks compared to poorly-governed banks. On the other hand, capital adequacy and loan growth are higher compared to poorly-governed banks. As for bank characteristics, well-governed banks have smaller size, lower managerial efficiency, and lower non-interest revenue sources.

Table 2. Descriptive statistics by governance score (GOV) quartiles (1 lowest, 4 highest)

\begin{tabular}{|c|c|c|c|c|c|c|c|c|c|}
\hline Variable & Quartile & $\mathrm{N}$ & Min & Q1 & Mean & Median & Q3 & Max & Std Dev \\
\hline \multirow{4}{*}{$K(E)$} & 1 & 86 & -103.765 & -9.601 & -1.913 & 0.021 & 7.256 & 80.240 & 29.591 \\
\hline & 2 & 78 & -114.697 & -11.522 & -4.231 & 0.720 & 11.188 & 70.659 & 35.017 \\
\hline & 3 & 80 & -45.181 & -5.162 & 4.011 & 0.751 & 14.463 & 68.576 & 23.460 \\
\hline & 4 & 83 & -41.567 & -27.649 & -3.205 & -3.543 & 0.925 & 60.050 & 27.177 \\
\hline \multirow{4}{*}{$K(D)$} & 1 & 86 & -2.509 & -0.926 & 0.363 & 0.074 & 1.187 & 9.178 & 2.141 \\
\hline & 2 & 78 & -3.536 & -1.532 & -0.412 & -0.279 & 0.399 & 2.731 & 1.306 \\
\hline & 3 & 80 & -4.514 & -1.753 & 0.138 & -1.037 & 0.222 & 23.074 & 5.002 \\
\hline & 4 & 83 & -5.345 & -2.061 & -1.163 & -1.452 & 0.053 & 3.301 & 1.489 \\
\hline \multirow{4}{*}{ GOV } & 1 & 86 & -2.280 & -1.316 & -1.184 & -1.127 & -0.914 & -0.494 & 0.366 \\
\hline & 2 & 78 & -0.876 & -0.630 & -0.358 & -0.361 & -0.191 & 0.292 & 0.322 \\
\hline & 3 & 80 & -0.255 & 0.007 & 0.323 & 0.292 & 0.577 & 1.475 & 0.416 \\
\hline & 4 & 83 & 0.360 & 0.702 & 1.253 & 1.460 & 1.630 & 2.257 & 0.538 \\
\hline \multirow{4}{*}{ BSIZE } & 1 & 86 & 5.000 & 9.000 & 11.221 & 11.000 & 13.000 & 24.000 & 3.145 \\
\hline & 2 & 78 & 3.000 & 8.000 & 10.859 & 10.000 & 14.000 & 24.000 & 4.698 \\
\hline & 3 & 80 & 2.000 & 7.000 & 8.038 & 8.000 & 9.500 & 13.000 & 2.230 \\
\hline & 4 & 83 & 3.000 & 6.000 & 6.855 & 7.000 & 8.000 & 9.000 & 1.690 \\
\hline \multirow{4}{*}{ COMP } & 1 & 86 & 54.545 & 84.615 & 86.731 & 88.889 & 90.909 & 94.444 & 7.462 \\
\hline & 2 & 78 & 50.000 & 83.333 & 85.815 & 88.889 & 92.857 & 100.000 & 10.400 \\
\hline & 3 & 80 & 33.333 & 75.000 & 78.703 & 85.714 & 88.889 & 92.308 & 14.327 \\
\hline & 4 & 83 & 33.333 & 66.667 & 75.847 & 83.333 & 87.500 & 100.000 & 17.576 \\
\hline \multirow{4}{*}{$D U A L$} & 1 & 86 & 0.000 & 0.000 & 0.186 & 0.000 & 0.000 & 1.000 & 0.391 \\
\hline & 2 & 78 & 0.000 & 0.000 & 0.410 & 0.000 & 1.000 & 1.000 & 0.495 \\
\hline & 3 & 80 & 0.000 & 0.000 & 0.388 & 0.000 & 1.000 & 1.000 & 0.490 \\
\hline & 4 & 83 & 0.000 & 1.000 & 0.771 & 1.000 & 1.000 & 1.000 & 0.423 \\
\hline \multirow{4}{*}{ FOR } & 1 & 86 & 0.000 & 0.000 & 10.259 & 0.000 & 18.700 & 55.000 & 14.716 \\
\hline & 2 & 78 & 0.000 & 0.000 & 23.289 & 35.704 & 40.000 & 70.250 & 21.657 \\
\hline & 3 & 80 & 0.000 & 0.000 & 37.191 & 40.170 & 63.015 & 95.350 & 32.892 \\
\hline & 4 & 83 & 0.000 & 49.000 & 68.011 & 78.400 & 95.360 & 100.000 & 33.998 \\
\hline \multirow{4}{*}{ INST } & 1 & 86 & 0.000 & 31.100 & 57.075 & 71.900 & 79.840 & 100.000 & 29.254 \\
\hline & 2 & 78 & 23.060 & 71.760 & 82.353 & 84.655 & 100.000 & 100.000 & 20.127 \\
\hline & 3 & 80 & 65.910 & 77.460 & 89.820 & 97.275 & 100.000 & 100.000 & 12.053 \\
\hline & 4 & 83 & 70.000 & 98.200 & 97.637 & 99.614 & 100.000 & 100.000 & 6.012 \\
\hline
\end{tabular}




\begin{tabular}{|c|c|c|c|c|c|c|c|c|c|}
\hline \multirow{4}{*}{$C 1$} & 1 & 86 & 3.650 & 17.840 & 28.398 & 22.490 & 32.100 & 100.000 & 19.891 \\
\hline & 2 & 78 & 13.820 & 25.200 & 48.010 & 40.000 & 59.440 & 100.000 & 30.072 \\
\hline & 3 & 80 & 16.660 & 39.730 & 62.171 & 51.000 & 95.350 & 100.000 & 29.863 \\
\hline & 4 & 83 & 33.260 & 60.000 & 81.637 & 94.527 & 99.300 & 100.000 & 21.611 \\
\hline \multirow{4}{*}{$L L P$} & 1 & 86 & -4.531 & -0.934 & 0.553 & -0.369 & 1.806 & 7.554 & 2.840 \\
\hline & 2 & 78 & -5.325 & -1.295 & 0.016 & -0.292 & 1.127 & 10.240 & 2.342 \\
\hline & 3 & 80 & -4.327 & -1.511 & -0.386 & -0.438 & 0.264 & 16.513 & 2.653 \\
\hline & 4 & 83 & -5.524 & -1.460 & -0.158 & -0.577 & 0.463 & 10.048 & 2.772 \\
\hline \multirow{4}{*}{$L G R O$} & 1 & 86 & -25.057 & -11.558 & -4.728 & -3.596 & 1.388 & 32.572 & 10.509 \\
\hline & 2 & 78 & -35.134 & -14.479 & -2.868 & -6.245 & -1.339 & 97.421 & 22.509 \\
\hline & 3 & 80 & -31.722 & -6.147 & 5.674 & -1.172 & 10.121 & 98.329 & 24.871 \\
\hline & 4 & 83 & -28.268 & -6.854 & 14.353 & 6.123 & 17.507 & 312.279 & 52.548 \\
\hline \multirow{4}{*}{ BETA } & 1 & 86 & -0.827 & -0.210 & 0.004 & 0.045 & 0.184 & 0.751 & 0.303 \\
\hline & 2 & 78 & -0.914 & -0.352 & -0.089 & -0.056 & 0.154 & 0.628 & 0.333 \\
\hline & 3 & 80 & -0.859 & -0.400 & -0.012 & 0.090 & 0.199 & 0.721 & 0.414 \\
\hline & 4 & 83 & -1.114 & -0.624 & -0.371 & -0.283 & -0.039 & 0.060 & 0.388 \\
\hline \multirow{4}{*}{ FLEV } & 1 & 86 & -13.129 & -1.430 & 0.871 & 1.204 & 3.551 & 22.693 & 6.246 \\
\hline & 2 & 78 & -15.186 & -1.535 & 1.222 & 1.676 & 4.539 & 7.609 & 4.439 \\
\hline & 3 & 80 & -15.297 & 0.707 & 1.468 & 2.414 & 4.367 & 6.909 & 4.724 \\
\hline & 4 & 83 & -13.564 & -1.688 & -0.034 & 1.192 & 3.045 & 6.191 & 4.483 \\
\hline \multirow{4}{*}{$L I Q$} & 1 & 86 & -27.971 & -6.057 & 5.684 & 1.417 & 16.619 & 69.966 & 20.853 \\
\hline & 2 & 78 & -77.213 & -21.172 & -9.763 & -10.676 & -2.686 & 57.926 & 23.680 \\
\hline & 3 & 80 & -61.473 & -19.322 & -2.144 & -10.154 & 1.259 & 151.777 & 38.368 \\
\hline & 4 & 83 & -38.213 & -21.783 & -14.723 & -15.508 & -6.821 & 34.352 & 12.606 \\
\hline \multirow{4}{*}{ SIZE } & 1 & 86 & -2.353 & -1.192 & -0.669 & -0.647 & -0.221 & 0.838 & 0.690 \\
\hline & 2 & 78 & -1.956 & -1.258 & -0.447 & -0.913 & 0.203 & 2.231 & 1.097 \\
\hline & 3 & 80 & -1.640 & -1.126 & -0.019 & -0.100 & 0.656 & 2.504 & 1.155 \\
\hline & 4 & 83 & -3.261 & -1.486 & -0.655 & -0.739 & -0.115 & 2.413 & 1.304 \\
\hline
\end{tabular}

To illustrate the change in study variables over time, Figure 1 below shows the trend over period 2000-2009 in governance quality index (Panel A) and cost of equity and cost of deposits (Panel B) for sample banks. The governance quality index shows a sharp increase starting in 2004, the year in which the 2003 law went into effect. Cost of equity (solid line) started a downward trend in 2004 with a few peaks in 2005 and 2007. Cost of deposits (dashes and dots) has decreased steadily starting in 2001. Both costs increased again sharply in 2009, but this may be due to the smaller sample size in 2009 than a genuine effect of economic activity.

Panel A: Governance Index

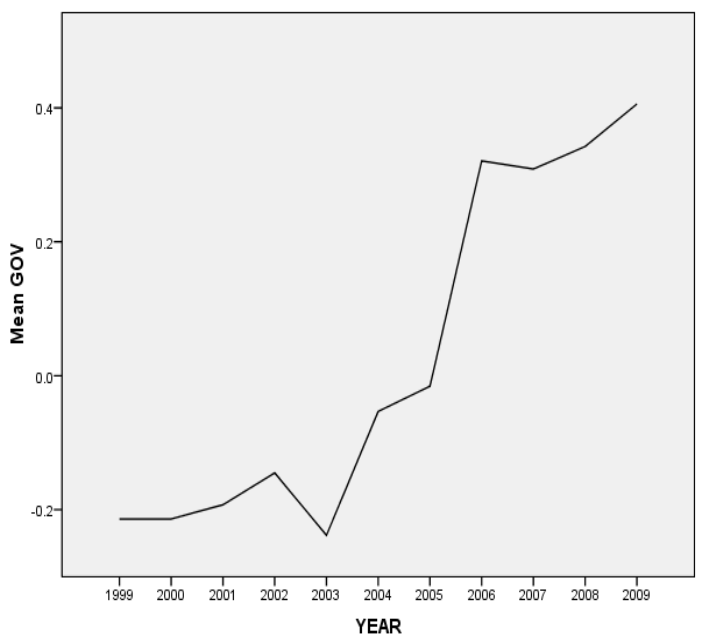

Panel B: Cost of equity capital and cost of deposits

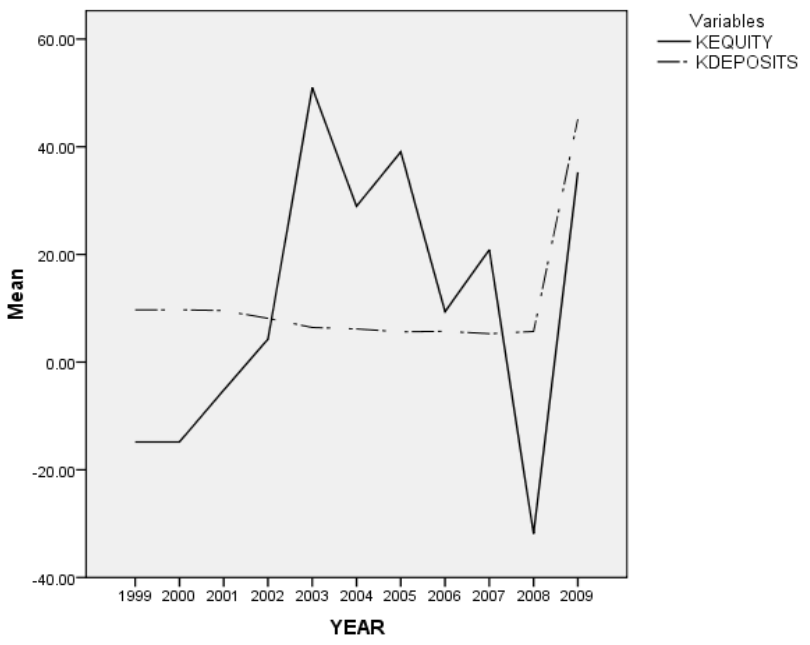

Figure 1. Governance Quality and Cost of Capital for Sample Banks by Year

Figure 1 shows sample banks' governance quality (Panel A) and cost of equity and deposits (Panel B) during 2000-2009. Cost of equity is shown as a solid line and cost of deposits is shown as a dashed and dotted line in Panel B. 


\subsection{Impact of Bank Governance Quality on Cost of Capital}

In this section, we describe the results of testing the hypothesis specified in Models (1) and (2). Pearson correlation coefficients for the variables are shown in Table 3. Panel (a) of Table 3 shows the cost of equity (Model 1) correlations, where the correlations between cost of equity, governance and other control variables are represented . Panel (b) of Table 3 shows the cost of deposits (Model 2) correlations, that is, the correlation relation between cost of deposits, governance and control variables are presented. Figures in Panel (a) in Table 3 indicate that $K(E)$ is insignificantly positively correlated with $G O V . K(E)$ is also significantly positively correlated with $B E T A$ and $R O A$, and negatively correlated to LLP. However, LIQ, SIZE, LGRO, CRISIS, GDPG, CPI, and LIST are insignificantly related to cost of Equity. On the other hand, the figures in Panel (b) in Table 4 show that $K(D)$ is significantly negatively correlated with $G O V . K(D)$ is also negatively significantly related to BETA, SIZE, LGRO, ROA, CRISIS, $G D P G$ and $C P I$. Moreover, $K$ (Deposits) is positively significantly related to $L L P$ and $L I Q$. Finally, Correlations show that $K$ (Deposits) is insignificantly related to LIST and FLEV.

Table 3. Correlation Coefficients

Panel (a). Cost of equity and governance components ( $\mathrm{n}=88$ obs., 1 -tailed sig. tests)

\begin{tabular}{|c|c|c|c|c|c|c|c|c|c|c|c|c|}
\hline & $K(E)$ & $\mathrm{GOV}$ & BETA & $L L P$ & $L I Q$ & SIZE & $L G R O$ & $R O A$ & CRISIS & $G D P G$ & $C P I$ & LIST \\
\hline \multirow{2}{*}{$K(E)$} & 1.00 & 0.03 & 0.59 & -0.18 & -0.10 & -0.02 & -0.05 & 0.22 & -0.01 & 0.02 & 0.00 & -0.05 \\
\hline & & 0.39 & 0.00 & 0.03 & 0.14 & 0.41 & 0.31 & 0.01 & 0.48 & 0.40 & 0.48 & 0.29 \\
\hline \multirow{2}{*}{ GOV } & 0.03 & 1.00 & -0.29 & -0.10 & -0.26 & -0.02 & 0.25 & 0.01 & 0.14 & 0.16 & 0.16 & -0.28 \\
\hline & 0.39 & & 0.00 & 0.06 & 0.00 & 0.37 & 0.00 & 0.41 & 0.06 & 0.00 & 0.00 & 0.00 \\
\hline \multirow{2}{*}{ BETA } & 0.59 & -0.29 & 1.00 & 0.17 & -0.04 & 0.06 & 0.04 & 0.35 & -0.02 & 0.02 & -0.02 & 0.24 \\
\hline & 0.00 & 0.00 & & 0.04 & 0.33 & 0.26 & 0.34 & 0.00 & 0.42 & 0.39 & 0.41 & 0.00 \\
\hline \multirow{2}{*}{$L L P$} & -0.18 & -0.10 & 0.17 & 1.00 & -0.12 & -0.21 & -0.18 & -0.64 & -0.01 & -0.04 & -0.02 & -0.06 \\
\hline & 0.03 & 0.06 & 0.04 & & 0.02 & 0.00 & 0.00 & 0.00 & 0.43 & 0.27 & 0.35 & 0.20 \\
\hline \multirow{2}{*}{$L I Q$} & -0.10 & -0.26 & -0.04 & -0.12 & 1.00 & -0.13 & -0.04 & 0.10 & 0.03 & 0.00 & 0.01 & -0.23 \\
\hline & 0.14 & 0.00 & 0.33 & 0.02 & & 0.01 & 0.28 & 0.04 & 0.26 & 0.50 & 0.45 & 0.00 \\
\hline \multirow{2}{*}{ SIZE } & -0.02 & -0.02 & 0.06 & -0.21 & -0.13 & 1.00 & -0.00 & 0.01 & 0.04 & 0.03 & 0.03 & -0.25 \\
\hline & 0.41 & 0.37 & 0.26 & 0.00 & 0.01 & & 0.48 & 0.46 & 0.25 & 0.26 & 0.34 & 0.00 \\
\hline \multirow{2}{*}{$L G R O$} & -0.05 & 0.25 & 0.04 & -0.18 & -0.04 & -0.00 & 1.00 & 0.15 & 0.09 & 0.10 & 0.07 & -0.04 \\
\hline & 0.31 & 0.00 & 0.34 & 0.00 & 0.28 & 0.48 & & 0.01 & 0.06 & 0.04 & 0.11 & 0.27 \\
\hline \multirow{2}{*}{$R O A$} & 0.22 & 0.01 & 0.35 & -0.64 & 0.10 & 0.01 & 0.15 & 1.00 & 0.00 & 0.00 & 0.02 & 0.19 \\
\hline & 0.01 & 0.41 & 0.00 & 0.00 & 0.04 & 0.46 & 0.01 & & 0.47 & 0.50 & 0.37 & 0.00 \\
\hline \multirow{2}{*}{ CRISIS } & -0.01 & 0.14 & -0.02 & -0.01 & 0.03 & 0.04 & 0.09 & 0.00 & 1.00 & 0.70 & 0.36 & -0.15 \\
\hline & 0.48 & 0.01 & 0.42 & 0.43 & 0.26 & 0.25 & 0.06 & 0.47 & & 0.00 & 0.00 & 0.00 \\
\hline \multirow{2}{*}{$G D P G$} & 0.02 & 0.16 & 0.02 & -0.04 & 0.00 & 0.03 & 0.10 & 0.00 & 0.70 & 1.00 & 0.42 & -0.19 \\
\hline & 0.40 & 0.00 & 0.39 & 0.27 & 0.50 & 0.26 & 0.04 & 0.50 & 0.00 & & 0.00 & 0.00 \\
\hline \multirow{2}{*}{$C P I$} & 0.00 & 0.16 & -0.02 & -0.02 & 0.01 & 0.03 & 0.07 & 0.02 & 0.36 & 0.42 & 1.00 & -0.18 \\
\hline & 0.48 & 0.00 & 0.41 & 0.35 & 0.45 & 0.34 & 0.11 & 0.37 & 0.00 & 0.00 & & 0.00 \\
\hline \multirow{2}{*}{ LIST } & -0.05 & -0.28 & 0.24 & -0.06 & -0.23 & -0.25 & -0.04 & 0.19 & -0.15 & -0.19 & -0.18 & 1.00 \\
\hline & 0.29 & 0.00 & 0.00 & 0.20 & 0.00 & 0.00 & 0.27 & 0.00 & 0.00 & 0.00 & 0.00 & \\
\hline
\end{tabular}


Panel (b). Cost of deposits and governance components ( $n=82$ obs., 1-tailed sig. tests)

\begin{tabular}{|c|c|c|c|c|c|c|c|c|c|c|c|c|c|}
\hline & $K(D)$ & $G O V$ & $B E T A$ & $L L P$ & $L I Q$ & $S I Z E$ & $L G R O$ & $R O A$ & CRISIS & $G D P G$ & $C P I$ & LIST & FLEV \\
\hline \multirow[t]{2}{*}{$K(D)$} & 1.00 & -0.48 & -0.35 & 0.36 & 0.21 & -0.36 & -0.31 & -0.44 & -0.24 & -0.40 & -0.22 & 0.16 & 0.12 \\
\hline & . & 0.00 & 0.00 & 0.00 & 0.05 & 0.00 & 0.01 & 0.00 & 0.03 & 0.00 & 0.04 & 0.11 & 0.17 \\
\hline \multirow[t]{2}{*}{$G O V$} & -0.48 & 1.00 & -0.18 & -0.29 & -0.14 & 0.19 & 0.32 & 0.20 & 0.27 & 0.34 & 0.22 & -0.17 & -0.07 \\
\hline & 0.00 & . & 0.08 & 0.01 & 0.14 & 0.07 & 0.01 & 0.06 & 0.01 & 0.00 & 0.04 & 0.09 & 0.30 \\
\hline \multirow[t]{2}{*}{ BETA } & -0.35 & -.18 & 1.00 & 0.18 & 0.03 & 0.32 & -0.23 & 0.04 & -0.03 & -0.00 & 0.07 & 0.25 & -0.06 \\
\hline & 0.00 & 0.08 & . & 0.08 & 0.41 & 0.01 & 0.03 & 0.37 & 0.39 & 0.50 & 0.29 & 0.02 & 0.31 \\
\hline \multirow[t]{2}{*}{$L L P$} & 0.36 & -0.29 & 0.18 & 1.00 & -0.08 & -0.34 & -0.51 & -0.74 & -0.10 & -0.05 & -0.19 & 0.03 & 0.29 \\
\hline & 0.00 & 0.01 & 0.08 & . & 0.26 & 0.00 & 0.00 & 0.00 & 0.22 & 0.34 & 0.07 & 0.41 & 0.01 \\
\hline \multirow[t]{2}{*}{$L I Q$} & 0.21 & -0.14 & 0.03 & -0.08 & 1.00 & 0.27 & -0.01 & 0.08 & 0.02 & -0.06 & 0.14 & -0.05 & -0.08 \\
\hline & 0.05 & 0.14 & 0.41 & 0.26 & . & 0.02 & 0.46 & 0.28 & 0.45 & 0.32 & 0.14 & 0.36 & 0.26 \\
\hline \multirow[t]{2}{*}{ SIZE } & -0.36 & 0.19 & 0.32 & -0.34 & 0.27 & 1.00 & 0.19 & 0.30 & -0.00 & -0.03 & -0.00 & 0.12 & 0.08 \\
\hline & 0.00 & 0.07 & 0.01 & 0.00 & 0.02 & . & 0.07 & 0.01 & 0.49 & 0.41 & 0.49 & 0.16 & 0.27 \\
\hline \multirow[t]{2}{*}{$L G R O$} & -0.31 & 0.32 & -0.23 & -0.51 & -0.01 & 0.19 & 1.00 & 0.24 & 0.04 & 0.08 & 0.01 & -0.04 & 0.04 \\
\hline & 0.01 & 0.01 & 0.03 & 0.00 & 0.46 & 0.07 & . & 0.03 & 0.37 & 0.27 & 0.46 & 0.39 & 0.39 \\
\hline \multirow[t]{2}{*}{$R O A$} & -0.44 & 0.20 & 0.04 & -0.74 & 0.08 & 0.30 & 0.24 & 1.00 & 0.10 & -0.03 & 0.08 & -0.10 & -0.55 \\
\hline & 0.00 & 0.06 & 0.37 & 0.00 & 0.28 & 0.01 & 0.03 & . & 0.24 & 0.41 & 0.27 & 0.22 & 0.00 \\
\hline \multirow[t]{2}{*}{ CRISIS } & -0.24 & 0.27 & -0.03 & -0.10 & 0.02 & -0.00 & 0.04 & 0.09 & 1.00 & 0.78 & 0.61 & -0.33 & -0.08 \\
\hline & 0.03 & 0.01 & 0.39 & 0.22 & 0.45 & 0.49 & 0.37 & 0.24 & - & 0.00 & 0.00 & 0.00 & 0.25 \\
\hline \multirow[t]{2}{*}{$G D P G$} & -0.40 & 0.34 & -0.00 & -0.05 & -0.06 & -0.03 & 0.08 & -0.03 & 0.78 & 1.00 & 0.57 & -0.26 & 0.08 \\
\hline & 0.00 & 0.00 & 0.50 & 0.34 & 0.32 & 0.41 & 0.27 & 0.41 & 0.00 & . & 0.00 & 0.02 & 0.28 \\
\hline \multirow[t]{2}{*}{$C P I$} & -0.22 & 0.22 & 0.07 & -0.19 & 0.14 & -0.00 & 0.01 & 0.08 & 0.61 & 0.57 & 1.00 & -0.21 & -0.14 \\
\hline & 0.04 & 0.04 & 0.29 & 0.07 & 0.14 & 0.49 & 0.46 & 0.27 & 0.00 & 0.00 & - & 0.05 & 0.13 \\
\hline \multirow[t]{2}{*}{$L I S T$} & 0.16 & -0.17 & 0.25 & 0.03 & -0.05 & 0.12 & -0.04 & -0.10 & -0.33 & -0.26 & -0.21 & 1.00 & 0.09 \\
\hline & 0.11 & 0.09 & 0.02 & 0.41 & 0.36 & 0.16 & 0.39 & 0.22 & 0.00 & 0.02 & 0.05 & • & 0.25 \\
\hline \multirow[t]{2}{*}{$F L E V$} & 0.12 & -0.07 & -0.06 & 0.29 & -0.08 & 0.08 & 0.04 & -0.55 & -0.08 & 0.08 & -0.14 & 0.09 & 1.00 \\
\hline & 0.17 & 0.30 & 0.31 & 0.01 & 0.26 & 0.27 & 0.39 & 0.00 & 0.25 & 0.28 & 0.13 & 0.25 & • \\
\hline
\end{tabular}

The table presents Pearson (upper triangle) and Spearman (lower triangle) correlations. See Appendix A for variable definitions.

Values shown in boldface represent coefficients that are significant at the $10 \%$ level or better.

Table 4 below presents the regression results for the impact of bank governance on bank cost of equity (Model 1) and cost of deposits (Model 2). 
Table 4. Results of Regression Analysis of Model 1 and 2

\begin{tabular}{|c|c|c|c|c|c|c|}
\hline \multirow[t]{5}{*}{ Dependent variable } & \multicolumn{3}{|c|}{$K(E)$} & \multicolumn{3}{|c|}{$K(D)$} \\
\hline & \multirow{2}{*}{\multicolumn{2}{|c|}{$\begin{array}{c}\text { Theorized relation } \\
\text { Model } 1 \text { (a) }\end{array}$}} & \multirow{4}{*}{$\begin{array}{c}\text { Ex-Post Analysis } \\
\text { Model } 1 \text { (a1) } \\
\text { Standardized } \\
\text { Coefficients }\end{array}$} & \multirow{2}{*}{\multicolumn{2}{|c|}{$\begin{array}{c}\text { Theorized relation } \\
\text { Model } 2 \text { (b) }\end{array}$}} & \multirow{4}{*}{$\begin{array}{c}\text { Ex-Post Analysis } \\
\text { Model } 2 \text { (b1) } \\
\text { Standardized } \\
\text { Coefficients }\end{array}$} \\
\hline & & & & & & \\
\hline & Pred. & Standardized Coefficients & & Pred. & Standardized & \\
\hline & Sign & Slativat & & Sign & Coefficients & \\
\hline GOV & - & $0.179 * * *$ & & - & $-.277 * * *$ & \\
\hline BSIZE & & & $-.358^{* * *}$ & & & .134 \\
\hline COMP & & & $.302 * *$ & & & .163 \\
\hline$D U A L$ & & & -.40 & & & .019 \\
\hline FOR & & & -.124 & & & $-.597 * * *$ \\
\hline INST & & & .104 & & & -.009 \\
\hline$C 1$ & & & .283 & & & $.297^{*}$ \\
\hline BETA & + & $1.133 * * *$ & $.686^{* * *}$ & + & $-.434 * * *$ & $-.304 * * *$ \\
\hline$L L P$ & + & $-.926^{* * *}$ & .089 & + & -.001 & -.048 \\
\hline$L I Q$ & + & $-.201 * * *$ & -.093 & + & $.212 * * *$ & .106 \\
\hline SIZE & - & $-.392 * * *$ & .043 & - & -.120 & .086 \\
\hline$L G R O$ & - & $-.214 * * *$ & .079 & - & $-.178^{*}$ & $-.222 * *$ \\
\hline$R O A$ & - & $-.640 * * *$ & $344^{* *}$ & - & $-.339 * *$ & $-.339 * *$ \\
\hline CRISIS & + & .071 & -.012 & + & $.243^{*}$ & $.237 *$ \\
\hline$G D P G$ & - & $-.142 *$ & -.057 & - & $-.430 * * *$ & $-.420 * * *$ \\
\hline$C P I$ & + & -.021 & -.066 & + & -.002 & -.038 \\
\hline LIST & - & $-.372 * * *$ & $-.235^{* *}$ & - & $.176^{* *}$ & .087 \\
\hline FLEV & & & & + & -.42 & -.111 \\
\hline F-Statistic & & $25.87 * * *$ & $5.33^{* * *}$ & & $10.31^{* * *}$ & $9.237 * * *$ \\
\hline $\mathrm{R}^{2}$ & & 0.74 & 0.62 & & 0.71 & 0.77 \\
\hline Adj. $R^{2}$ & & 0.71 & 0.51 & & 0.64 & 0.69 \\
\hline
\end{tabular}

See Appendix A for variable definitions. *, **, *** denote significance at $10 \%, 5 \%$ and $1 \%$, respectively. A significant $G O V$ coefficient suggests governance quality is an important determinant of bank cost of capital in Egypt. Table values are coefficient estimates from the following OLS regression model:

Model 1a: $K(E)=f(G O V, C R I S I S, L I Q, L L P, L G R O$, SIZE, BETA, ROA, LIST, FLEV, GDPG, CPI)

Model 1a1: K(E) $=f(B S I Z E, C O M P, D U A L, F O R, I N S T, C 1$, CRISIS, LIQ, LLP, LGRO, SIZE, BETA, ROA, LIST, FLEV , GDPG, $C P I)$

Model 2b: $K(D)=f(G O V, C R I S I S, L I Q, L L P, L G R O$, SIZE, BETA, ROA, LIST, FLEV, GDPG, CPI)

Model 2b1: $K(D)=f(B S I Z E, C O M P, D U A L, F O R$, INST, C1, CRISIS, LIQ, LLP, LGRO, SIZE, BETA, ROA, LIST, FLEV,GDPG, $C P I)$.

Table 4 presents the results of significance testing for Models 1 (a) and 2 (b). Regarding cost of equity capital, Model 1 (a) is highly significant at the .01 level and has an average explanatory power $\left(\mathrm{R}^{2}\right.$ is 0.742$)$ and adjusted $\mathrm{R}^{2}$ is 0.71 . Contrary to expectations, the coefficient on $G O V$ is significantly positive, not negative. This result indicates that governance quality is a significant determinant of cost of equity of Egyptian banks. The control variables $B E T A, L I Q$, $L L P, R O A, S I Z E, L G R O$ and LIST appear to have a highly significant impact on $K(E)$. As for the cost of deposits, 
Model 2 (b) is highly significant at the .01 level and has an average explanatory power $\left(\mathrm{R}^{2}\right.$ is 0.707$)$ and adjusted $\mathrm{R}^{2}$ is 0.64 . Parallel with expectations, the coefficient on $G O V$ is significantly negative. This result suggests that governance quality has been a major determinant of cost of deposits of Egyptian banks over the period 2000-2009. The control variables BETA, LIQ, ROA, LGRO, GDPG, CRISIS and LIST appear to have a significant impact on $K(D)$.

\subsection{Supplemental Analysis}

To determine the impact of each governance practice on the cost of equity and cost of deposits, and because the sign on the GOV coefficients in Models 1 (a) is in the opposite direction to that hypothesized, we perform supplemental analysis. We analyze the impact of the individual governance components (BSIZE, COMP, FOR, INST, Cl, and $D U A L)$ on $K(E)$ and $K(D)$. It must be noted that analyzing the effects of governance components on bank cost of equity and deposit capital is ex-post and no theory was created regarding the investigated relations and therefore no predictions are made for the directions of the signs. To test the separate effects of these components, we repeat the empirical testing of Model 1 (a) and 2 (b), after replacing the main independent variable GOV in the original models with governance components. Each model is an OLS regression model where the main independent variables are governance components.

The results of regressing $K(E)$ on governance components are shown as "Model 1 (a1)" under the "Ex-Post Analysis" title in Table 4. The F-statistic is significant at the .01 level and the explanatory power of the model is above average $\left(\mathrm{R}^{2}\right.$ is 0.62$)$ and the adjusted $\mathrm{R}^{2}$ is 0.51 . Empirical testing shows that BSIZE is significantly negatively related to $K(E)$, while $C O M P$ is significantly positively related to $K(E)$. On the other hand, the results of regressing $K(D)$ on governance components are shown as "Model 2 (b1)" under the "Ex-Post Analysis" title in Table 4. The F-statistic is significant at the .01 level and the explanatory power of the model is above average $\left(\mathrm{R}^{2}\right.$ is 0.77$)$ and the adjusted $\mathrm{R}^{2}$ is 0.69 . Results of empirical testing show that $K(D)$ is significantly negatively related to $F O R$, but significantly positively related to $C 1$. Based on this empirical evidence, we conclude that bank cost of equity is a function of board structure, specifically board size and composition. On the other hand, bank cost of deposits is a function of ownership structure primarily, specifically foreign ownership, and ownership concentration.

\section{Conclusion and Recommendations}

In this study, the impact of bank governance on cost of bank capital is examined by using a self-constructed governance index to test whether good bank governance improves and modernizes the Egyptian banking sector and makes it better able to face global competition. Being more competitive implies better financial and non-accounting-based financial performance, better protection for stockholder interests, and lower cost of capital. The results of this study should therefore be of interest to regulators, banking sector participants, economists, and other parties. Economic reforms in emerging markets such as Egypt should be guided by continuous research and data analysis.

In conducting this research, one major concern is the accuracy of data. We use KOMPASS EGYPT, Bankscope, bank financial statements, and Thomson Reuters 3000 Xtra stock price database to construct the dataset used to analyze the hypothesized models. To the extent that these data sources offer accurate data, the results of this study should be accurate, valid, and generalizable. However, we attempt to improve the accuracy of the results by adopting a set of controls in building the dataset. All financial figures for every bank are industry-adjusted, that is, variable industry average is deducted from the data value for each bank on the variable. Adjusting the data for industry average serves to avoid the effects of industry-wide fluctuations and to make the bank figures representative of the bank's standing among its industry. This treatment has been followed by Cornett et al. (2007) and others. We examine the impact of Egyptian bank governance, using a self-constructed governance index, on cost of bank equity capital and cost of bank deposits. Interestingly, empirical evidence shows that the relation between bank governance and the cost of equity and cost of deposits is significant. Unexpectedly, evidence shows that cost of equity capital is positively related to bank governance quality.

To analyze this relation and determine the governance measure that has the greatest effect on Egyptian banks' cost of equity capital, the impact of the components of the governance index on the cost of the equity is examined separately. Evidence shows that cost of equity of Egyptian banks is a function of board size and composition. Board size has a negative highly significant impact on cost of equity (consistent with Shah and Butt (2009) findings), while the presence of independent directors has a significantly positive relation with cost of equity, which is again consistent with Shah and Butt (2009) results but contradicts Ashbaugh et al. (2004) and other research based on the agency theory. 
Accordingly, banks with large boards and less non-executive directors have lower cost of capital. These findings contradict Pham et al. (2007) who argue that small independent boards reduce risk and thus lower cost of capital. The results may refer to the ability of dependent directors to obtain cheaper finance from different resources due to their bank specific knowledge. Banks have complicated and opaque structures due to their unobservable loan quality (Levine, 2004), therefore, bank executives have more information about the bank risk profile, and thus are more able to lower their cost of equity. In addition, banks with large boards will include large number of directors who possess a diverse set of qualifications and experiences and are able to mitigate bank managers' risk-taking behavior, resulting in lower cost of equity. These results are consistent with the findings of Shah and Butt (2009) who document a negative (positive) relation between board size (board composition) and cost of equity and argue that large board size prevents any stakeholder from hindering the process of decision-making. The results are also consistent with Ashbaugh et al. (2004) who argue that board independence is negatively related to cost of equity.

This result in particular is important because it means that cost of equity of Egyptian banks is not just related to accounting-based financial performance and risk but also related to how well a bank is run. Moreover, evidence shows that beta, bank size, loan growth opportunities, accounting-based financial performance (ROA), and listing on the stock exchange are significant determinants of cost of equity capital. In particular, large banks with small Beta, high growth opportunities, high performance (ROA) and listed on the stock exchange have lower cost of equity capital. Larger banks can obtain cheaper finance from different sources; these results are in line with results suggested by Easton (2004) and Cheng et al. (2006). Again, large Beta means high risk and high cost of capital, which support the prior research that reports positive relation between firm Beta and cost of capital (e.g. Botosan, 1997; Gode and Mohanram, 2003). Few growth opportunities will cause increase in cost of equity capital, similarly as documented by Easton (2004) and Huang et al. (2009). High ROA means better performance and stream of future cash flow that will be reflected in low cost of equity capital, while listing on the stock exchange indicates more monitoring and regulations that decrease cost of equity.

On the other hand, evidence indicates that bank cost of deposits is negatively related to governance quality and the relation is highly significant. More specifically, it is positively related to ownership concentration, while negatively and significantly related to foreign ownership. The reason could be that foreign owners may be able to obtain funds from foreign sources at a lower cost compared to other banks. An alternative explanation is that foreign-owned banks are more sophisticated and are able to offer more integrated and unique services compared to local banks. The unique services allow the foreign banks to pay comparatively less interest on deposits compared to local banks. The customer loyalty enjoyed by these banks permits them to pay interest on deposits that is lower than the market. Bank cost of deposits is also a function of beta, accounting-based financial performance, liquidity, GDP Growth, loan growth opportunities, stock exchange listing, and global banking crisis. The variables chosen for analysis in this study are economic indicators that are instrumental to the success of the Egyptian banking sector. Maintaining high standards for these economic indicators is critical for maintaining a strong banking sector.

\section{Future Research}

The results of the analyses suggest that much research effort is needed in this area. One promising area for future research and regulation is how future-banking regulations in Egypt can aim at improving these two dimensions, perhaps by including research-based provisions in future banking laws that provide incentives for banks exhibiting continuous improvements in operating efficiency, organizational learning, employee empowerment, streamlined business processes, community relations, and timely adoption of modern IT systems.

Another future research area is to investigate in depth the effects of CEO characteristics on performance, governance, and cost of capital. Many studies examine the effect of CEO characteristics on board independence such as CEO age and tenure (Hermalin and Weisbach, 1998; Linck et al., 2008), the CEO-Chairman duality (Linck et al., 2008; Raheja, 2005), the CEO bargaining power (his strong decision making power) due to his perceived ability (Hermalin and Weisbach, 1998). This important factor has not been examined before for Egyptian banks, especially due to the lack of time series data on CEO characteristics. However, new data sources, such as KOMPASS EGYPT, contain relevant corporate governance data.

\section{References}

Anderson, R. C., Mansi, S. A., \& Reeb, D. M. (2004). Board characteristics, accounting report integrity and the cost of debt. Journal of Accounting \& Economics, 37 (3), 315-342. http://dx.doi.org/10.1016/j.jacceco. 2004.01.004 
Anderson, R. C., Mansi, S. A., \& Reeb, D. M. (2003). Founding family ownership and the agency cost of debt. Journal of Financial Economics, 68, 263-285. http://dx.doi.org/10.1016/s0304-405x(03)00067-9

Andrade, S. C., Bernile, G., \& Hood III, F. M. (2014). SOX, corporate transparency, and the cost of debt. Journal of Banking \& Finance, 38, 145-165. http://dx.doi.org/10.2139/ssrn.1257002

Ashbaugh, H., Collins, D., \& LaFond, R. (2004). Corporate governance and cost of equity capital. Working Paper, University of Wisconsin-Madison, University of Iowa and Massachusetts Institute of Technology. http://dx. doi.org/10.2139/ssrn.639681

Ashbaugh, H., Collins, D., \& LaFond R. (2006). The effects of corporate governance on firms' credit ratings. Journal of Accounting \& Economics, 42, 203-243. http://dx.doi.org/10.1016/j.jacceco.2006.02.003

Barnes, M. L., \& Lopez, J. A. (2006) Alternative measures of the Federal Reserve Banks' cost of equity capital. Journal of Banking \& Finance, 30, 1687-711. http://dx.doi.org/10.1016/j.jbankfin.2005.09.005

Barth, J., Caprio, G. \& Levine, R. (2004). Bank regulation and supervision: what works best? Journal of Financial Intermediation, 13, 205-248. http://dx.doi.org/10.1016/j.jfi.2003.06.002

Basel Committee on Banking Supervision. (2006). Basel II: International convergence of capital measurement and capital standards: A revised framework - comprehensive version. Bank for International Settlements, Switzerland.

Baumann, U., \& Nier, E. (2004). Disclosure, volatility, and transparency: An empirical investigation into the value of bank disclosure. Economic Policy Review, 10 (2), 31-45.

Beasley, M. S. (1996). An empirical analysis of the relation between the board of director composition and financial statement fraud. Accounting Review, 71 (4), 443-466.

Bhojraj, S., \& Sengupta, P. (2003). The effect of corporate governance on bond ratings and yields: the role of institutional investors and outside directors. Journal of Business, 76(3), 455-475. http://dx.doi.org/10.1086/ 344114.

Botosan, C. A. (1997). Disclosure level and the cost of equity capital. Accounting Review, 72 (3), 323-349.

Brickley, J. A., Coles J. L., \& Jarrell, G. (1997). Leadership structure: Separating the CEO and Chairman of the Board. Journal of Corporate Finance, 3, 189-220. http://dx.doi.org/10.1016/s0929-1199(96)00013-2

Caprio, G. J., \& Levine, R. (2002). Corporate governance of banks: Concepts and international observations. Procedings of the Global Corporate Governance Forum research Network Meeting. April 5.

Central Bank of Egypt. (2007). Annual Report for the year 2006/2007. Central Bank of Egypt: Cairo, Egypt.

Chen, K. C. W., Chen, Z., \& Wei, K. C. (2003). Disclosure, corporate governance, and the cost of equity capital: evidence from Asia's emerging markets. Working Paper, Hong Kong University of Science and Technology. http://dx.doi.org/10.2139/ssrn.422000

Chen, K. C.W., Chen, Z., \& Wei, K. C. (2009). Legal Protection of investors, corporate governance, and the cost of equity capital. Journal of Corporate Finance, 15, 273-289. http://dx.doi.org/10.1016/j.jcorpfin.2009.01.001

Cheng, C. S. A., Collins, D., \& Huang, H. H. (2006). Shareholder rights, financial disclosure and the cost of equity capital. Review of Quantitative Finance \& Accounting, 27,175-204. http://dx.doi.org/10.1016/j.jcorpfin.2009.01.001

Chow, C., \& Wong-Boren, A. (1987). Voluntary financial disclosure by Mexican corporations. Accounting Review, 3 , 533-541.

Claessens, S. (2003). Corporate governance and development: Review of the literature and outstanding research issues. Proceedings of the Global Governance Forum Donors Meeting, The Hague, Netherlands. http://dx.doi.org/10.1787/9789264106598-en

Claessens, S., Djankov, S., Fan, J., \& Lang, L. (2002). Disentangling the incentive and entrenchment effects of large shareholdings. Journal of Finance, 57, 2741-71. http://dx.doi.org/10.1111/1540-6261.00511

Cornett, M. M., Marcus, A. J., Saunders, A., \& Tehranian, H. (2007). The impact of institutional ownership on corporate operating performance. Journal of Banking \& Finance, 31(6), 1771-1794. http://dx.doi.org/10.1016/j.jbankfin.2006.08.006 
Diamond, D., \& Verrecchia, R. E. (1991). Disclosure, liquidity and the cost of equity capital. Journal of Finance, 46 (4), 1325-1359. http://dx.doi.org/10.1111/j.1540-6261.1991.tb04620.x

Easton, P. (2004). PE ratios, PEG ratios, and estimating the implied expected rate of return on equity capital. Accounting Review, 79, 73-95. http://dx.doi.org/10.2308/accr.2004.79.1.73

Giroud, X., \& Mueller, H. (2011). Corporate governance, product market competition, and equity prices. Journal of Finance, 66 (2), 563-600.

Gode, D., \& Mohanram, P. (2003). Inferring the cost of equity using the Ohlson-Jüettner model. Review of Accounting Studies, 8, 399-431. http://dx.doi.org/10.1023/a:1027378728141

Gompers, P., Ishii, J., \& Metrick, A. (2003). Corporate governance and equity prices. Quarterly Journal of Economics, 118 (1), 107-155. http://dx.doi.org/10.1162/00335530360535162

Guedhami, O., \& Mishra, D. (2009). Excess control, corporate governance, and implied cost of equity: international evidence. Financial Review, 44 (4), 489-524. http://dx.doi.org/10.1111/j.1540-6288.2009.00227.x

Hermalin, B. E. \& Weisbach, M. S. (1998). Endogenously chosen boards of directors and their monitoring of the CEO. American Economic Review, 88, 96-118.

Huang, H., Wang, Q., \& Zhang, X. (2009). The effect of CEO ownership and shareholder rights on cost of equity capital. Corporate Governance: An International Review, 9 (3), 255-270. http://dx.doi.org/10.1108/14720700910964325

Huang, W., \& Zhu, T. (in press). Foreign institutional investors and corporate governance in emerging markets: evidence of a split-share structure reform in China. Journal of Corporate Finance. http://dx.doi.org/10.2139/ ssrn.1917094.

Jensen, M. (1993). The modern industrial revolution, exit, and the failure of internal control systems. Journal of Finance, 48, 831-880. http://dx.doi.org/10.2307/2329018

Jensen, M., \& Meckling, W. (1976). Theory of the firm: Managerial behaviour, agency costs, and capital structure. Journal of Financial Economics, 3, 305-360. http://dx.doi.org/10.1016/0304-405x(76)90026-x

Klock, M. S., Mansi, S. A., \& Maxwell, W.F. (2005). Does corporate governance matter to bondholders? Journal of Financial \& Quantitative Analysis, 40 (4), 693-719. http://dx.doi.org/10.2139/ssrn.527663

La Porta, R., Lopez-de-Silanes, F., \& Shleifer, A. (1997). Legal determinants of external finance. Journal of Finance, 52, 1131-50. http://dx.doi.org/10.1111/j.1540-6261.1997.tb02727.x

La Porta, R., Lopez-de-Silanes, F., Shleifer, A., \& Vishny, R. (2002). Investor protection and corporate valuation. The Journal of Finance, 57, 1147-1170. http://dx.doi.org/10.1111/1540-6261.00457

La Porta, R., Lopez-de-Silanes, F., Shleifer, A., \& Vishny, R. (2000). Investor protection and corporate governance. Journal of Financial Economics, 58, 3-27. http://dx.doi.org/10.2139/ssrn.192549

Levine, R. (2004). The corporate governance of banks: A concise discussion of concepts and issues. World Bank Policy Research, Working Paper Series No. 3404. http://dx.doi.org/10.1596/1813-9450-3404

Linck, J. S., Netter, J. M., \& Yang T. (2008). The determinants of board structure. Journal of Financial Economics, 87 (2), 308-328. http://dx.doi.org/10.1016/j.jfineco.2007.03.004

Lintner, J. (1965). The valuation of risk assets and the selection of risky investments in stock portfolios and capital budgets. Review of Economics \& Statistics, 47 (1), 13-37. http://dx.doi.org/10.2307/1924119

Lombardo, D., \& Pagano, M. (2000). Law and equity markets: A simple model, in: Convergence and diversity of corporate governance regimes and capital markets. Luc Renneboog et al. (eds), Oxford University Press, London. http://dx.doi.org/10.2139/ssrn.209312

Markowitz, H. M. (1959). Portfolio selection: Efficient diversification of investments, New York: Wiley. http://dx.doi.org/10.2307/3006625

Morellec, E., Nikolov, B., \& Schürhoff, N. (2012). Corporate governance and capital structure dynamics. Journal of Finance, 67(3), 803-848. http://dx.doi.org/10.1111/j.1540-6261.2012.01735.x

Naceur, S. B., \& Kandil, M. (2009). The impact of capital requirements on banks' cost of intermediation and performance: The case of Egypt. Journal of Economics \& Business, 61 (1), 70-89. http://dx.doi.org/10.1016/j.jeconbus.2007.12.001 
Pham, P. K., Suchard, J., \& Zein, J. (2007). Corporate governance, cost of capital, and performance: Evidence from Australian Firms. Working Paper, University of New South Wales. http://dx.doi.org/10.2139/ ssrn. 1015986

Poterba, J. (1991). Comparing the cost of capital in the United States and Japan: A survey of methods. Federal Reserve Bank of New York Quarterly Review, 15, 20-32. http://dx.doi.org/10.2139/ssrn.1187571

Qian, M., \& Yeung, B. (in press). Bank financing and corporate governance. Journal of Corporate Finance, In Press.

Raheja, C. G. (2005). Determinants of board size and composition: A theory of corporate boards. Journal of Financial \& Quantitative Analysis, 40, 283-306. http://dx.doi.org/10.1017/s0022109000002313

Sengupta, P. (1998). Corporate disclosure quality and the cost of debt. Accounting Review, 73 (4), 459-74.

Shaffer, S. (1995). Rethinking Disclosure Requirements. Federal Reserve Bank of Philadelphia Business Review, May/June, 15-29.

Shah, S. Z. A., \& Butt, S. A. (2009). The impact of corporate governance on the cost of equity: Empirical evidence from Pakistani listed companies. Lahore Journal of Economics, 14 (1), 139-171. http://dx.doi.org/10.5539/ijbm.v4n2p50

Sharpe, W.F. (1964). Capital asset Prices: A Theory of market equilibrium under conditions of risk. Journal of Finance, 19 (3), 425-442. http://dx.doi.org/10.2307/2977928

Shleifer, A., \& Vishny, R.W. (1997). A survey of corporate governance. Journal of Finance, 52, 737-783. http://dx.doi.org/10.3386/w5554

Yermack, H. (1996). Higher market valuation of companies with a small board of directors. Journal of Financial Economics, 40: 185-211. http://dx.doi.org/10.1016/0304-405x(95)00844-5

Zimmer, S., \& McCauley, R.N. (1991). Bank cost of capital and international competition. Federal Reserve Bank of New York Quarterly Review, 15, 33-59. http://dx.doi.org/10.2307/1122950 
Appendix A: Variable Definitions

\begin{tabular}{|c|c|c|}
\hline Variables & Measurement & Source \\
\hline \multicolumn{3}{|c|}{ Cost of capital proxies } \\
\hline$K(E)$ & Cost of equity capital (\%): Cost of equity capital estimated using CAPM. & 1 \\
\hline$K(D)$ & Cost of deposits $(\%)$ : Interest on deposits divided by total deposits. & 2 \\
\hline \multicolumn{3}{|c|}{ Governance quality } \\
\hline$B S I Z E$ & Board size: Number of directors on the board. & 3 \\
\hline COMP & Board structure (\%): Proportion of non-executives directors on the board. & 3 \\
\hline$D U A L$ & $\begin{array}{l}\text { Leadership structure: Dummy variable coded as } 0 \text { if the CEO is also the board } \\
\text { chair and } 1 \text { if not. }\end{array}$ & 3 \\
\hline$C 1$ & Ownership concentration: Proportion of shares held by the largest blockholder. & 3 \\
\hline FOR & Foreign ownership: Proportion of shares held by foreign investors. & 3 \\
\hline INST & $\begin{array}{l}\text { Institutional ownership (\%): Proportion of shares held by non-foreign institutional } \\
\text { investors, including the Egyptian government. }\end{array}$ & 3 \\
\hline$G O V$ & $\begin{array}{l}\text { Governance index: Bank i's corporate governance quality score in year t, measured } \\
\text { as a multidimensional composite index generated by factor analysis of bank i's } \\
\text { score in year t on each of the following indicators: board size, board composition, } \\
\text { CEO/Chairman duality, institutional ownership percentage, foreign ownership } \\
\text { percentage, and largest blockholder ownership percentage }\end{array}$ & $\begin{array}{l}\text { Calculated using } \\
\text { factor analysis }\end{array}$ \\
\hline \multicolumn{3}{|c|}{ Risk factors } \\
\hline$L I Q$ & Liquidity (\%): Liquid assets of the bank divided by total assets. & 2 \\
\hline BETA & Beta: Covariance of monthly bank returns and EGX30 returns over a 36 months. & Calculated \\
\hline$L L P$ & $\begin{array}{l}\text { Credit risk (\%): Loan loss provisions measured as total loan losses divided by total } \\
\text { loans. }\end{array}$ & 2 \\
\hline$F L E V$ & Financial leverage $(\%)$ : Total debt divided by total assets. & 2 \\
\hline \multicolumn{3}{|c|}{ Macroeconomic variables } \\
\hline$G D P G$ & Real GDP growth (\%): Official annual real GDP growth figures. & 4 \\
\hline$C P I$ & Inflation rate (\%): Official annual Consumer Price Index. & 4 \\
\hline CRISIS & $\begin{array}{l}\text { Global financial crisis year: Dummy variable coded as } 1 \text { for fiscal year } 2008 \text { and } 0 \\
\text { otherwise. }\end{array}$ & Author-constructed \\
\hline \multicolumn{3}{|c|}{ Bank characteristics } \\
\hline$S I Z E$ & Bank size: Natural logarithm of total assets. & 2 \\
\hline LIST & $\begin{array}{l}\text { Stock listing: Dummy variable coded as } 1 \text { if bank } i \text { is listed on a stock exchange in } \\
\text { year t, } 0 \text { otherwise. }\end{array}$ & 3 \\
\hline$L G R O$ & Loan growth opportunities: Bank's average net loan growth during the last 3 years. & 2 \\
\hline$R O A$ & $\begin{array}{l}\text { Accounting-based financial performance: Return on assets }(\%) \text { measured as net } \\
\text { income divided by average assets. }\end{array}$ & 2 \\
\hline
\end{tabular}

$1=$ Reuters 3000 Xtra; 2 = Bankscope database; 3 = KOMPASS Egypt; 4 = Ministry of Finance. 


\section{Notes}

Note 1. The Basel Committee on Banking Supervision was established by the Bank for International Settlements (BIS) to improve the quality of banking supervision worldwide. In 1988, 2001, and 2011, BCBS developed three versions of what came to be known as the Basel Accords I, II, and III, respectively. The Accords mandate that banks must hold capital in proportion to their credit and liquidity risks. The risk-based capital ratio measures a bank's capital with respect to the default risk of its on- and off-balance sheet credit exposures and the liquidity of its asset portfolios. The financial instruments that qualify as capital for regulatory purposes are fairly strictly defined.

Note 2. Standard \& Poor's 2002 Corporate Ratings Criteria, 29 October 2002.

Note 3. KOMPASS EGYPT is owned by Fiani \& Partners, a firm that specializes in providing financial information products primarily directed to the investment and credit community. It issues the Financial Yearbook annually in print edition. The Yearbook has two types of financial listings: full financial statements and highlights for the current year.

Note 4. Data validation of the Financial Yearbook financial information has been conducted for a sample of 20 banks for the period 2006-2007 by comparing their financial information with data included in the financial statements issued by the firms. However, we could only validate 5 firms for the period 1997-1998 due to unavailability of firm financial statements. Validation showed that financial statement data in the Yearbook is highly accurate.

Note 5. All measures were hand collected from the KOMPASS EGYPT directory of Egyptian firms economic information and sample firms' financial statements, including board information.

Note 6. In Markowitz's model, an investor selects a portfolio that will minimize the variance of portfolio return, given expected return, or maximize expected return, given variance. Thus, the Markowitz model is called a "mean-variance model" and assumes investors are efficient, risk averse and utility maximizing investors who select points that are located on the efficient frontier (called the minimum variance frontier) and hence, the specific portfolio selected will depend on the individual investor's risk-return utility function. Therefore, when choosing among portfolios, investors care only about the mean and variance of their one-period investment return (single period of investment) and select a portfolio at time $\mathrm{t}-1$, which produces a stochastic return at $\mathrm{t}$.

Note 7. The variable FLEV was included as control variable for the cost of equity model (Model 1) but was found to be non-significant and was hence excluded from the model. 